\title{
Special issue of FOA10 in honor of our colleagues in Japan and New Zealand
}

This issue and also the February 2011 issue resulting from the FOA 10 meeting held in Japan, are dedicated to our colleagues from Japan and New Zealand who have been severely hit by earthquakes and a tsunami. Apart from effects on the economy of these countries, the events have more dramatically and directly affected the lives of our colleagues by loss or injury to themselves, family or friends. In some cases, their University or industrial facilities have been damaged or destroyed and it will take a long time to restore to normal. Ironically, the FOA 10 participants visited the Nojima Fault Museum on the conference excursion and could see firsthand the results of the major 7.3 earthquake that hit the Kobe area and whose epicenter was right where the conference was held on Awaji Island. But we all have seen the images of the badly hit areas in the recent disasters both in Japan and New Zealand, and we can only wish our colleagues and their compatriots strength and courage for rebuilding their environment and life. 